\title{
Targeting highly conserved 3'-untranslated region of pecluviruses for sensitive broad-spectrum detection and quantitation by RT-PCR and assessment of phylogenetic relationships
}

\author{
B. Dieryck ${ }^{\mathrm{a}}$, P. Delfosse ${ }^{\mathrm{b}, 1}$, A.S. Reddy ${ }^{\mathrm{c}}$, C. Bragard ${ }^{\mathrm{a}, *}$ \\ a Université catholique de Louvain, Earth and Life Institute, Applied Microbiology - Phytopathology, Croix du Sud, 2/3, B-1348 Louvain-la-Neuve, Belgium \\ ${ }^{\mathrm{b}}$ International Crops Research Institute for the Semi-Arid Tropics, Sadoré, BP-12404 Niamey, Niger \\ ' International Crops Research Institute for the Semi-Arid Tropics, ICRISAT Asia Center, Patancheru 502324, Andra Pradesh, India
}

\section{Article history:}

Received 16 April 2010

Received in revised form 5 August 2010

Accepted 9 August 2010

Available online 17 August 2010

\section{Keywords:}

Peanut clump virus

Broad-spectrum detection

Virus quantitation

3'-Untranslated region

\begin{abstract}
A B S T R A C T
The 3'-end region of many virus isolates has been shown to possess conserved sequences in addition to the presence of numerous genomic and subgenomic RNAs. Utilizing these sequences, a broad-spectrum reverse transcription-polymerase chain reaction protocol has been developed to detect all the known Indian peanut clump virus and Peanut clump virus isolates, that cause peanut clump diseases in West Africa and India. The primers were targeted at the highly conserved 3'-untranslated regions of the PCV RNA- 1 and RNA-2. The conservation was confirmed by sequencing these untranslated regions of RNA- 1 for six isolates and RNA-2 for one isolate. The conserved structure of the RNA- 1 and RNA-2 was observed and the importance of this region for the virus survival was confirmed. The primers were also designed for virus quantitation using a Taqman ${ }^{\circledR}$-based real-time RT-PCR. The use of RT-PCR and real-time quantitative RT-PCR improved the sensitivity of PCV detection compared to ELISA. RT-PCR also led to the detection of IPCV and PCV on two new natural hosts: Oldenlandia aspera and Vigna subterranea. Real-time RT-PCR is considered to be an ideal tool for identifying resistant sources to both IPCV and PCV.
\end{abstract}

(C) 2010 Elsevier B.V. All rights reserved.

\section{Introduction}

Peanut clump is a damaging disease of groundnut (Arachis hypogaea). It is caused by two pecluviruses, Peanut clump virus (PCV) and Indian peanut clump virus (IPCV) (Torrance and Mayo, 1997), first described in India (Sundararaman, 1927) and subsequently in West Africa (Trochain, 1931). Both viruses are carried by the obligate parasitic protist Polymyxa graminis. They are found on cereals such as sorghum (Sorghum bicolor), pearl millet (Pennisetum glaucum), maize (Zea mays) and sugarcane (Saccharum officinarum), and can also affect bread wheat (Triticum aestivum) (Delfosse et al., 2002).

IPCV is also transmitted by seed at rates varying from $<3.5 \%$ to $17 \%$, depending on the groundnut genotype, and from $48 \%$ to more than 55\% in seed collected from plants infected through seeds (Reddy et al., 1998). Natural resistance has not yet been found in groundnut genotypes, and cultural practices only reduce the disease incidence, rather than controlling the infection (Reddy et

\footnotetext{
* Corresponding author. Tel.: +32 10474023; fax: +32 10478697.

E-mail address: claude.bragard@uclouvain.be (C. Bragard).

1 Present address: Centre de Recherche Public - Gabriel Lippmann, 41 rue du Brill, L-4422 Belvaux, Grand-Duché de Luxembourg, Belgium.
}

al., 2008). The lack of control measures indicates a real need for efficient detection methods, and this is reinforced by the seed transmission ability of the virus, especially in monocotyledonous crops that also host the vector $P$. graminis, resulting in the long-term persistence of the virus in the soil. Sensitive detection methods are indispensable for virus detection in quarantine, and to prevent virus spread through seed.

Traditionally, such viruses have been detected in the field because they cause conspicuous stunting symptoms in groundnut crops. Nonetheless, the disease could be confused with groundnut rosette disease because of similarity of symptoms. In addition, both IPCV and PCV do not cause overt symptoms in cereals thus necessitating sensitive and reliable detection methods. Several immunological methods, utilizing polyclonal and monoclonal antibodies have been used for virus detection (Huguenot et al., 1989; Reddy et al., 1998). This approach revealed a diversity of serotypes and serogroups in Africa and India (Manohar et al., 1995). Wesley et al. (1996) have shown that a probe corresponding to the 3 '-terminal 742 nucleotides of IPCV RNA-1 was able to detect IPCV and PCV, in RNA and plant extracts even if the sequences targeted were not fully conserved. A sensitive specific broad-spectrum RT-PCR technique and real-time quantitative RT-PCR (RT-qPCR) for pecluvirus diagnosis and quantitation, based on a study of the conservation of the 3'-untranslated region (UTR) of RNA-1 and RNA-2 of the peclu- 
viruses, is proposed. The technique offers considerable potential for diagnosis of clump disease, germplasm conservation and for crop breeding to develop cultivars with disease resistance.

\section{Materials and methods}

\subsection{Plant samples}

Tests for detection of PCV were carried out on a total of 351 plants. Up to 305 samples from 15 plant species, either weeds or species included in the crop rotation were collected from groundnut fields in India and West Africa. These plants included two Ageratum conyzoïdes, 76 A. hypogaea, two Celosia argentea, five Cynodon dactylon, 34 Dactyloctenium aegyptium, two Euphorbia heterophylla, six Euphorbia hirta, 59 Oldenlandia aspera, 83 Oldenlandia corymbosa, 10 P. glaucum, 10 S. officinarum, 10 S. bicolor, two Tridax procumbens, two T. aestivum and two Vigna subterranea. In addition, 36 and 10 mechanically inoculated Phaseolus vulgaris and Nicotania benthamiana, respectively, were tested.

\subsection{Virus sources}

Seven PCV/IPCV sources from India (IPCV-D: Durgapura, IPCV-H: Hyderabad and IPCV-L: Ludhiana) and West Africa (PCV-B: Burkina Faso, PCV-M: Mali, PCV-N: Niger and PCV-S: Senegal) were used as virus source. The virus denomination follows that used by Naidu et al. (2003). These seven isolates were conserved at $-70^{\circ} \mathrm{C}$ and were mechanically inoculated on $N$. benthamiana for multiplication prior to utilizing them in the experiments presented in this study.

\subsection{ELISA}

A penicillinase-based DAS-ELISA was performed as described by Reddy et al. (1998) for the experiment on versatility of the method while a phosphatase-based DAS-ELISA was performed as described by Nolt et al. (1988) to compare DAS-ELISA with PCR and real-time quantitative RT-PCR (RT-qPCR). All tested samples were checked five times. The optical density at $620 \mathrm{~nm}\left(\mathrm{OD}_{620}\right)$ was measured with the Multiskan Ascent 354 (Labsystems, Helsinki, Finland).

\subsection{Nucleic acid extract}

Extracts were taken from frozen samples. Total RNA was extracted from $300 \mathrm{mg}$ of samples (leaves or roots) using the FastRNA ${ }^{\circledR}$ Pro Green Kit (Qbiogene, MP Biomedicals, Illkirch, France). The samples were crushed using the Fastprep ${ }^{\circledR}$ system (Qbiogene, MP Biomedicals, Illkirch, France), following the manufacturer's instructions for optimal RNA extraction from plants. The extraction process was also tested with both dry and fresh samples. Nucleic acid was also extracted using a faster procedure that had been suggested by Thomson and Dietzgen (1995) and allowed the use of direct sap extracts.

\subsection{Reverse transcription}

For broad-spectrum detection, cDNA synthesis was performed in two steps. First, $10.5 \mu \mathrm{l}$ of reaction mix containing $1 \mu \mathrm{l}$ of primer J8 corresponding to the extremity of both viral RNA molecules (Miller et al., 1996), $8.5 \mu$ l of diethylpyrocarbonate (DEPC) treated water and $1 \mu \mathrm{l}$ of RNA were incubated at $65^{\circ} \mathrm{C}$ for $10 \mathrm{~min}$. Second, a reaction mix composed of $4 \mu$ l of M-MLV RT buffer (Promega Corporation, Madison, WI, USA ), $2 \mu \mathrm{l}$ of dNTP ( $20 \mathrm{nmol}), 0.25 \mu \mathrm{l}$ of M-MLV Reverse Transcriptase (200 U/ $\mu \mathrm{l}$ ) (Promega Corporation, Madison, WI, USA) and $3.25 \mu \mathrm{l}$ of DEPC treated water was added to the first reaction mix. The total volume $(20 \mu \mathrm{l})$ was incubated at $42^{\circ} \mathrm{C}$ for $60 \mathrm{~min}$.
Table 1

Plant species tested by RT-PCR and DAS-ELISA. Number of plants tested and number of positive plants using both techniques.

\begin{tabular}{llccc}
\hline Host plants & Origin & Number & RT-PCR J8-J9 & ELISA \\
\hline Ageratum conyzö̈des & India & 2 & 0 & 0 \\
Arachis hypogaea & India & 6 & 6 & 6 \\
& Senegal & 47 & 25 & 1 \\
& Mali & 21 & 12 & 0 \\
& Burkina Faso & 2 & 2 & 2 \\
Celosia argentea & India & 2 & 0 & 0 \\
Cynodon dactylon & India & 5 & 3 & 3 \\
Dactyloctenium & India & 34 & 25 & 20 \\
aegyptium & & & & \\
Euphorbia heterophylla & India & 2 & 0 & 0 \\
Euphorbia hirta & India & 6 & 0 & 0 \\
Nicotiana benthamiana & Mecha. inoc. & 10 & 10 & Not tested \\
Oldenlandia aspera & India & 59 & 42 & 22 \\
Oldenlandia corymbosa & India & 83 & 51 & 10 \\
Pennisetum glaucum & Niger & 10 & 10 & Not tested \\
Phaseolus vulgaris & Mecha. inoc. & 36 & 36 & Not tested \\
Saccharum officinarum & Burkina Faso & 10 & 10 & Not tested \\
Sorghum bicolour & Niger & 10 & 10 & Not tested \\
Tridax procumbens & India & 2 & 0 & 0 \\
Triticum aestivum & India & 2 & 2 & 0 \\
Vigna subterranea & Mali & 2 & 2 & \\
\hline
\end{tabular}

\subsection{Primers and probe}

Primer J9 (forward) (5'-CGAGCCATAGAGCACGGTTGTGGG-3') was designed to match the conserved $3^{\prime}$-end of RNA-1 and RNA-2 (Table 1).

In order to quantify IPCV and PCV, a RT-qPCR was developed. Primer PCVBD2F-forward (5'-AGDTGTCGGGAGTGTCAAG-3') was designed to amplify, with the J8 primer, the $3^{\prime}$-end of RNA-1 and RNA-2. Taqbd1, a Taqman ${ }^{\circledR}$ probe $\left(5^{\prime}\right.$-ACCAGCAGTCTACGCCAGCCACT-3') was developed, and was labelled at the $5^{\prime}$-end with the fluorescent reporter dye 6-FAM (6-carboxyfluorescein) and at the 3 '-end with the BHQ-1 quencher. The probe and primers were provided by Eurogentec S.A. (Liège, Belgium).

\subsection{RT-PCR detection}

For RT-PCR detection, the cycling times and temperature were $94{ }^{\circ} \mathrm{C}$ for $2 \mathrm{~min}$ ( $\left.1 \mathrm{cycle}\right), 94^{\circ} \mathrm{C}$ for $30 \mathrm{~s}, 62^{\circ} \mathrm{C}$ for $30 \mathrm{~s}, 72^{\circ} \mathrm{C}$ for $30 \mathrm{~s}$ (30 cycles) and $72{ }^{\circ} \mathrm{C}$ for $7 \mathrm{~min}$ ( 1 cycle). The reaction component for each sample was $26.25 \mu \mathrm{l}$ sterile water, $5 \mu \mathrm{l} \mathrm{MgCl} 2$ (25 mM), $10 \mu \mathrm{l}$ Green Gotaq ${ }^{\circledR}$ Flexi buffer (Promega Corporation, Madison, WI, USA), $1.5 \mu \mathrm{l}$ dNTPs ( $20 \mathrm{nmol}), 1 \mu \mathrm{l}$ each primer ( $20 \mathrm{pmol}), 0.25 \mu \mathrm{l}$ Gotaq $^{\circledR}$ polymerase $(5 \mathrm{U} / \mu \mathrm{l})$ (Promega) and $5 \mu \mathrm{l}$ cDNA.

\subsection{Quantitation}

The real-time quantitative PCR was performed using the iCycler $\mathrm{IQ}^{\mathrm{TM}}$ Real-Time Detection system of Biorad (Hercules, CA). For each sample tested, the reaction mix contained $0.75 \mu l$ of each primer, $18 \mu \mathrm{l}$ of DEPC treated water and $25 \mu$ l of $\mathrm{qPCR}^{\mathrm{TM}}$ Mastermix (Eurogentec, Liège, Belgium), and $0.5 \mu \mathrm{l}$ of probe ( $100 \mathrm{nmol}$ ). Then, $45 \mu \mathrm{l}$ of the mix was prepared per reaction and $5 \mu$ l of cDNA was added. The PCR was performed under the following conditions: one step of $2 \mathrm{~min}$ at $50^{\circ} \mathrm{C}$, one step of $10 \mathrm{~min}$ at $95^{\circ} \mathrm{C}, 40$ cycles of $15 \mathrm{~s}$ at $95^{\circ} \mathrm{C}$, $20 \mathrm{~s}$ at $60^{\circ} \mathrm{C}$ and $40 \mathrm{~s}$ at $72^{\circ} \mathrm{C}$ with the fluorescence recorded after each elongation phase. The samples were maintained at $4{ }^{\circ} \mathrm{C}$. The quantitation of PCV/IPCV was done by comparing the $C_{\mathrm{t}}$ (threshold cycle) value of the sample and the $C_{t}$ values obtained for four serial dilutions of a standard. This standard allowed comparing the different quantitative real-time PCRs. The standard was a sequence produced with J8-J9 primers and cloned in the pGEM-T ${ }^{\circledR}$ Vector System II (Promega Corporation, Madison, WI). The construction 


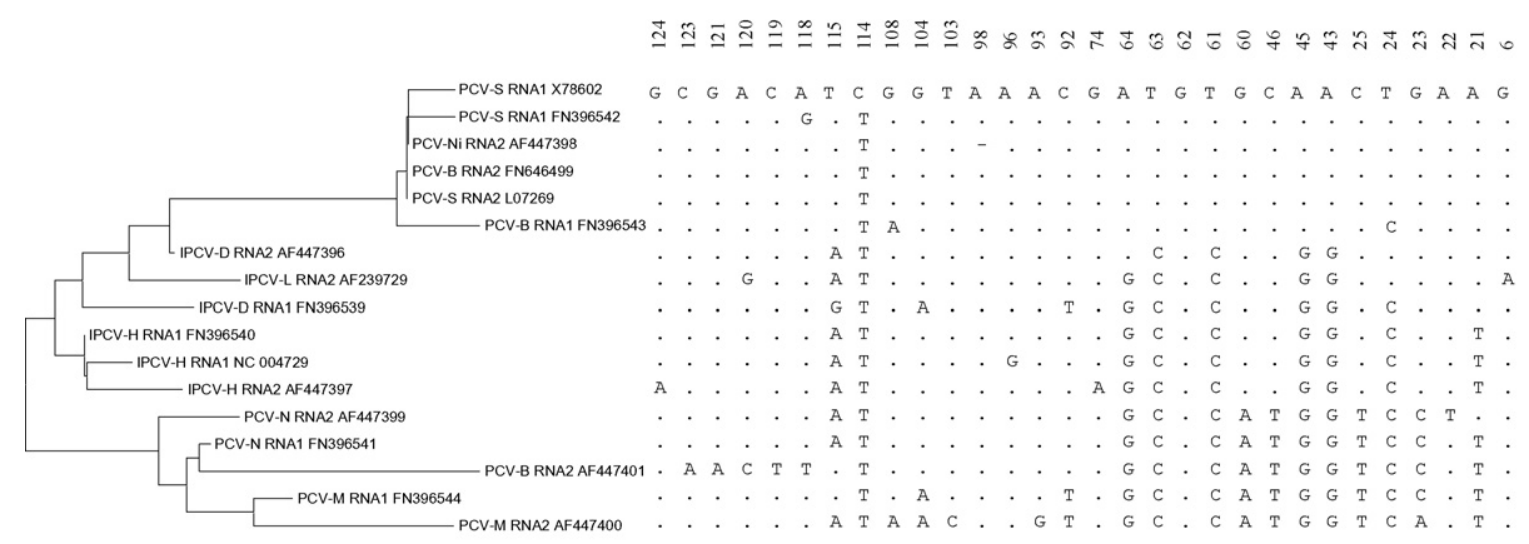

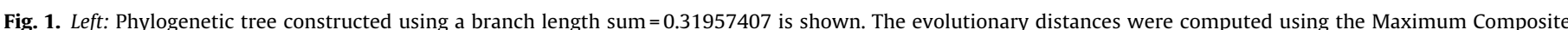

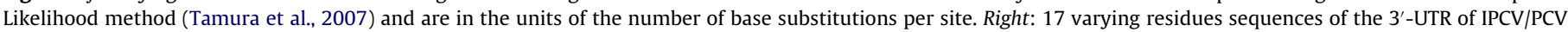
RNA-1 and RNA-2 compared to the PCV-S RNA-1 X78602, numbered from the 3'-extremity of the viral sequences.

was purified with the QIAprep ${ }^{\circledR}$ Spin Miniprep (Qiagen, Crawley, UK) following the manufacturer's instructions.

The sensitivity of the probe was evaluated by comparing sample (already used to compare ELISA and RT-PCR) dilutions to $1 / 10$, $1 / 100,1 / 1000,1 / 3000,1 / 6000,1 / 10,000,1 / 30,000$ and $1 / 60,000$.

\subsection{Cloning}

Clones of the RNA-1 3 '-end of six PCV/IPCV isolates (IPCV-D, IPCV-H, PCV-B, PCV-M, PCV-N, and PCV-S) were produced using pGEM-T $^{\circledR}$ Vector System II (Promega Corporation, Madison, WI). Amplicons of the $3^{\prime}$-end were obtained with a RT-PCR using the J8 reverse primer and BD3RNA1F (5'-TGGYTACTCTTGTGGTATGCC$3^{\prime}$ ) as the forward primer specifically targeting the RNA- 1 . The reverse transcription was performed as described above with J8 primer. The PCR was performed under the following conditions: the cycling times and temperature were $94{ }^{\circ} \mathrm{C}$ for $2 \mathrm{~min}$ ( 1 cycle), $94{ }^{\circ} \mathrm{C}$ for $2 \mathrm{~min}, 58^{\circ} \mathrm{C}$ for $30 \mathrm{~s}, 72^{\circ} \mathrm{C}$ for $45 \mathrm{~s}$ ( 30 cycles) and $72{ }^{\circ} \mathrm{C}$ for $7 \mathrm{~min}$ ( 1 cycle). The components of the reaction for each sample was $26.25 \mu \mathrm{l}$ sterile water, $5 \mu \mathrm{l} \mathrm{MgCl}_{2}(25 \mathrm{mM}), 10 \mu \mathrm{l} \mathrm{Green} \mathrm{Gotaq}{ }^{\circledR}$ Flexi buffer (Promega Corporation, Madison, WI), $1.5 \mu \mathrm{l}$ dNTPs ( $20 \mathrm{nmol}), 1 \mu \mathrm{l}$ each primer $(20 \mathrm{pmol}), 0.25 \mu \mathrm{l} \mathrm{Gotaq}{ }^{\circledR}$ polymerase $(5 \mathrm{U} / \mu \mathrm{l})$ (Promega Corporation, Madison, $\mathrm{WI})$ and $5 \mu \mathrm{l}$ cDNA.

\subsection{Sequencing}

Sequencing was carried out using the primers M13F (forward primer 5'-GTAAAACGACGGCCAG-3') and M13R (reverse primer $5^{\prime}$-CAGGAAACAGCTATGAC- $3^{\prime}$ ) provided with the pGEM-T ${ }^{\circledR}$ Vector System II (Promega Corporation, Madison, WI) with the aim of assessing the conservation of the 3'-UTR to develop the primers and probe for a Taqman RT-qPCR. The sequencing was carried out using a Beckman Coulter CEQTM 2000 XL (Beckman Coulter, Fullerton, CA). All the samples were sequenced twice with each forward and reverse primer.

Sequences obtained were aligned using a multiple alignment editor program, Jalview 2.4 (Clamp et al., 2004) and phylogenetic trees were conducted using MEGA version 4 (Tamura et al., 2007).

\section{Results}

\subsection{Conservation of the $3^{\prime}$-end}

In Fig. 1, 17 sequences of the 3'-UTR of RNA-1 and RNA-2 using the neighbor-joining method (Saitou and Nei, 1987) were aligned for constructing a phylogenetic tree. These 17 sequences were
$124 \mathrm{nt}$ long. Seven of them were newly deposited in the EMBL Database (FN396539 (IPCV-D RNA-1), FN396540 (IPCV-H RNA-1), FN396541 (PCV-N RNA-1), FN396542 (PCV-S RNA-1), FN396543 (PCV-B RNA-1), FN646499 (PCV-B RNA-2), FN396544 (PCV-M RNA1)) and 10 had already been published (Herzog et al., 1994; Miller et al., 1996; Naidu et al., 2000, 2003). The isolates were grouped into two African clusters and one Indian cluster (Fig. 1). The Indian cluster appeared to be intermediate between the African clusters. Nucleotide sequence identity between the 3'-extremity of RNA-2 was higher than $85 \%$, as observed by Naidu et al. (2003). For RNA-1, nucleotide sequence identity was higher than $8 \%$. By comparison, nucleotide sequence identity in the whole sequence was $79 \%$ for RNA- 1 and $60 \%$ for RNA-2.

\subsection{3'-End secondary structure}

T-RNA-like structures (TLS) of the 17 sequences of 3'-UTR were compared using the model described by Goodwin and Dreher (1998) (Fig. 2). Structures were grouped according to the clusters obtained (Fig. 1). Mutation in the main valine identity nucleotides (lack of A in the middle of GAC anticodon), shown as an empty box in Fig. 2, was observed only in the PCV-S RNA-2 sequence. The D-loop structure of PCV-S RNA-1 (accession nos. X78602, FN396542) and PCV-B RNA-2 (accession no. AF447401) appeared to be an exception. In all other sequences, a $C$ residue in the $D$-loop was replaced by $\mathrm{T}$, resulting in a new $\mathrm{T}$-A bases pair inducing a smaller D-loop.

\subsection{Versatility of the RT-PCR method}

Primers designed for amplifying the 3'-UTR end allowed all the currently known IPCV and PCV isolates to be detected (Fig. 3). The technique was also tested on 17 PCV/IPCV host plant species listed in Section 2 (Table 1). The virus was detected on all plant species tested excepting A. conyzoïdes, C. argentea, E. heterophylla, E. hirta and $T$. procumbens.

\subsection{Comparison of ELISA, RT-PCR and RT-qPCR}

The RT-PCR was compared with the penicillinase-based DASELISA using plant samples from 12 species from four countries in the Indian sub-continent and West Africa (Table 1). The virus was detected in 246 positive samples on the 351 plants tested by RT-PCR (70\%), compared with 66 detections out of the 275 plants tested by ELISA (24\%). The technique enabled the detection of the virus in $V$. subterranea and in the hosts that did not produce overt symptoms. 


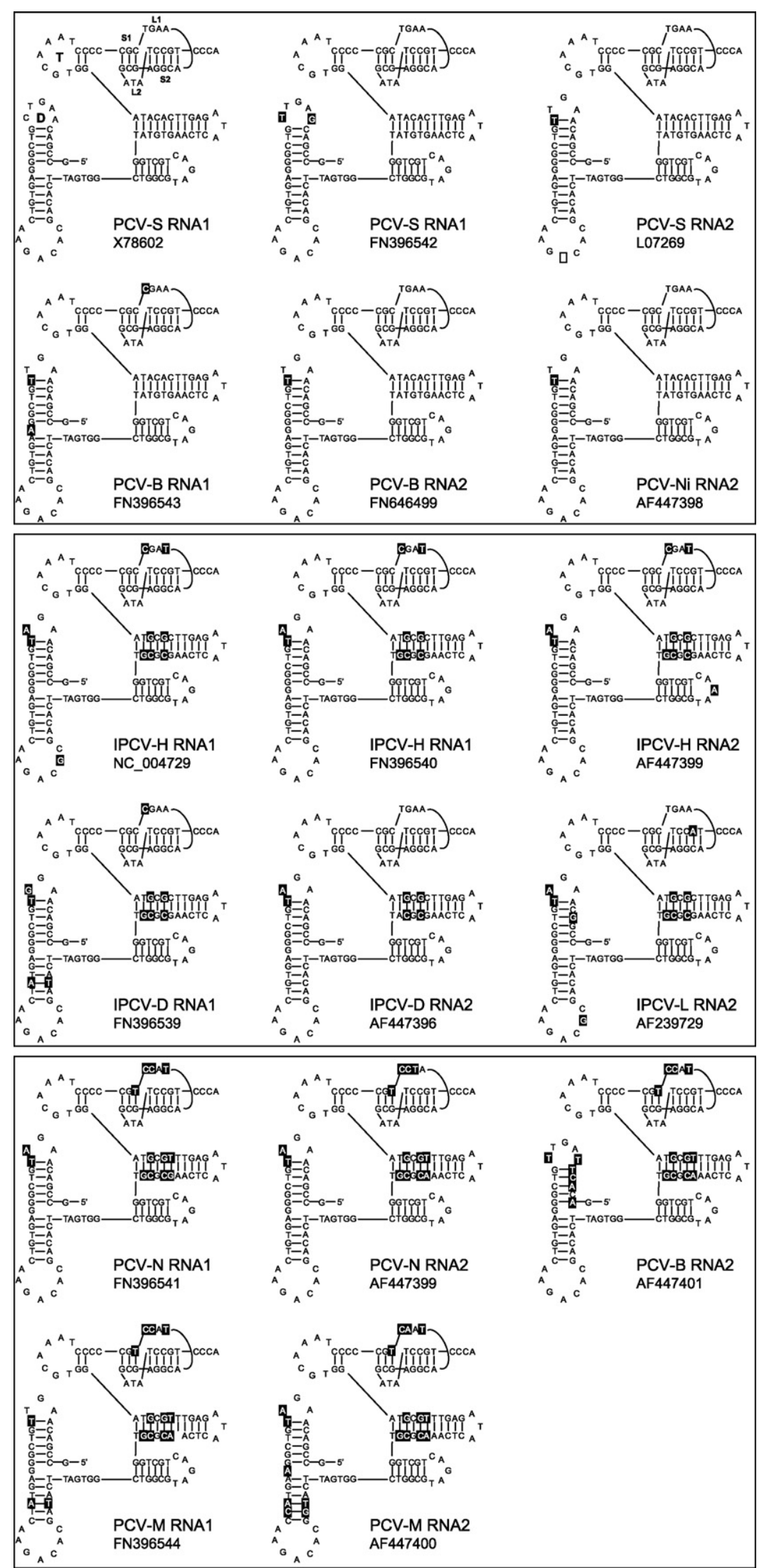

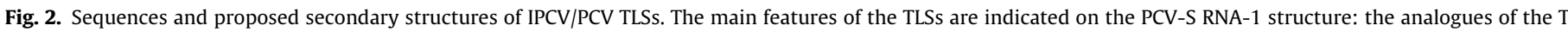

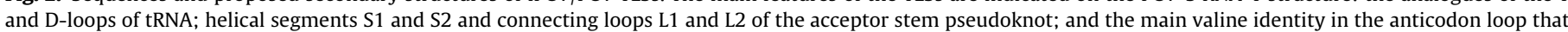

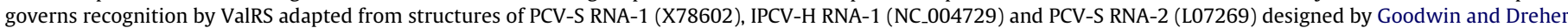
(1998). Nucleotides that differ from the PCV-S RNA-1 are shown in reverse shading. The single deletion is shown as an empty box. 


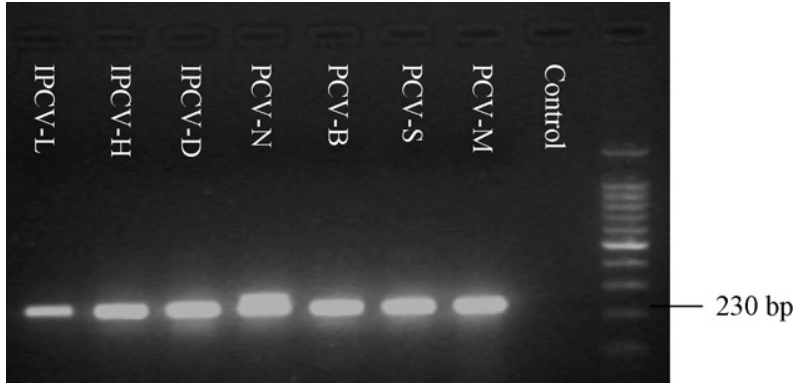

Fig. 3. RT-PCR detection of seven IPCV/PCV isolates using the J8-J9 pair of primers, RNA was extracted from mechanically inoculated $N$. benthamiana. Negative control is an extract of healthy $N$. benthamiana.

For the sensitivity test, a RNA extraction solution was diluted to $1 / 2,1 / 4,1 / 8,1 / 16,1 / 32,1 / 64,1 / 128$ and $1 / 256$ for phosphatasebased DAS-ELISA and up to $1 / 512,1 / 1024,1 / 2048$ and $1 / 4096$ for PCR. Fig. 4 compares OD $_{620}$ measurements for sample dilutions with the RT-PCR results. Adjusted $\mathrm{OD}_{620}$ values, twice as those from healthy controls, were considered positive. In the phosphatasebased system, a low absorbance value indicated that no conjugate was bound, whereas high absorbance values indicated that the conjugate was bound (i.e. the virus was present). RT-PCR proved to be at least 128 times more sensitive than DAS-ELISA (Fig. 4).

A quantitative real-time RT-PCR was developed targeting the 3 '-end conserved sequence using Taqbd1 probe (Fig. 5). Although minor nucleotide substitutions (Fig. 1) have been recorded in vari- ous IPCV and PCV isolates, all the isolates (IPCV-L, IPCV-H, IPCV-D, PCV-B, PCV-M, PCV-N, PCV-S) tested were successfully detected and could be quantified. When plant extracts were diluted to $1 / 30,000$, the RTq-PCR using Taqbd1 probe was able to detect dilution up to $1 / 6000$ corresponding to a 188 and 1.5 times more sensitive virus detection than ELISA (detection up to $1 / 32$ ) and RT-PCR (detection up to $1 / 4094$ ).

\section{Discussion}

\subsection{The 3'-UTR of the pecluviruses is highly conserved}

IPCV and PCV showed considerable differences in homology, depending on the part of the genome sequenced. Nucleotide sequences identities between RNA-2 sequences of eight isolates (IPCV-D, IPCV-H, IPCV-L, PCV-B, PCV-M, PCV-N, PCV-Ni, PCV-S) ranged from $58 \%$ to $79 \%$. The nucleotide sequence identity between the coat protein gene of IPCV/PCV isolates ranged from $37 \%$ to $56 \%$, at amino acid level (Naidu et al., 2003). On the RNA-1, the nucleotide sequence identity of the P15 suppressor of gene silencing was also far less pronounced than for the polymerase-helicase domains. In comparison, the 3 '-end was highly conserved (88\% for RNA-1 and $85 \%$ for RNA-2 of nucleotide sequence identity), thus offering a potential target for broad-spectrum detection by RT-PCR. Conservation of the 3'-UTR was verified by the alignment of seven IPCV/PCV isolates and the 10 already published sequences. Despite the high percentage of identity between 3'-UTR of RNA1 and RNA-2 of isolates from different geographical origins, there

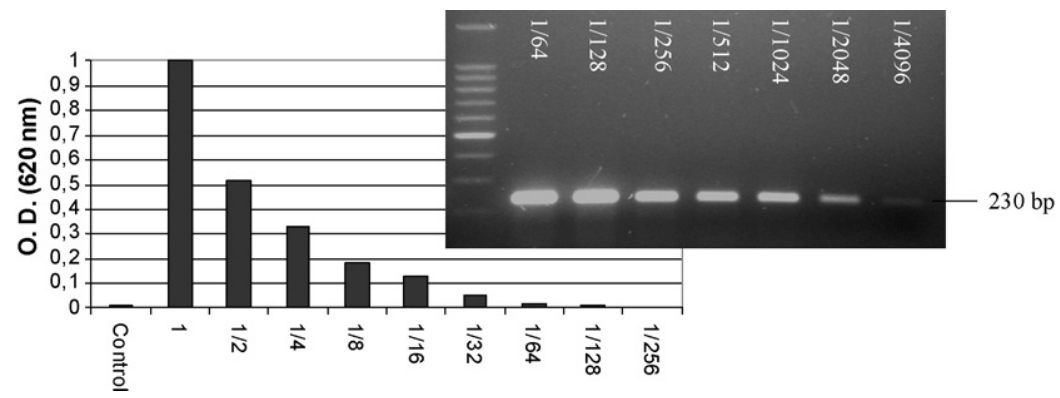

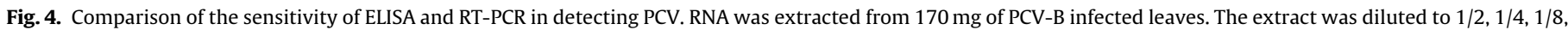
$1 / 16,1 / 32,1 / 64,1 / 128$ and $1 / 256$ for ELISA. RT was made from the extract and cDNA was diluted to 1/64, 1/128, 1/256, 1/512, 1/1024, 1/2048 and 1/4096 for RT-PCR.

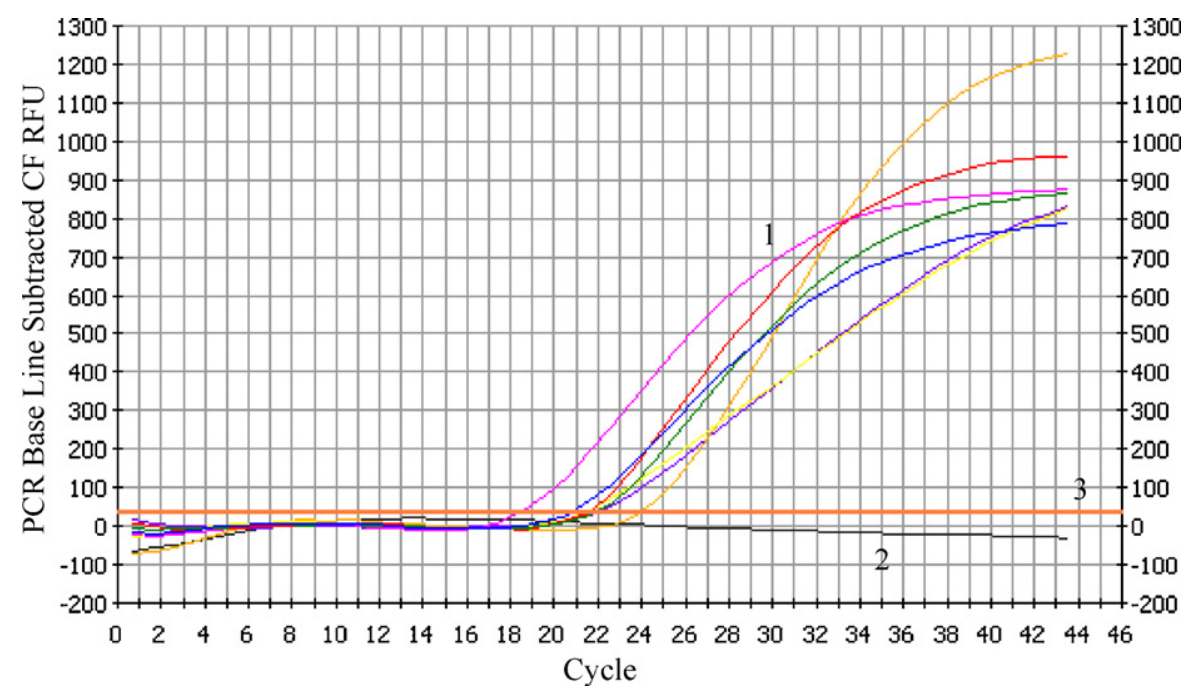

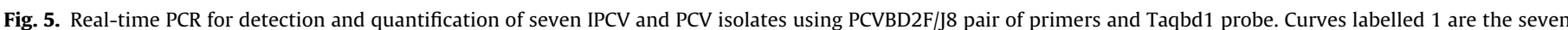

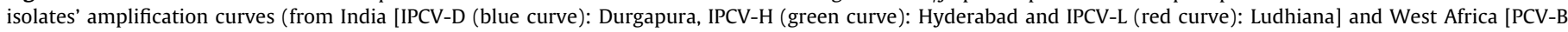

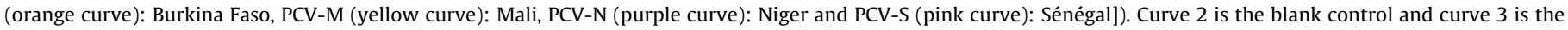
threshold detection line. (For interpretation of references to color in this figure legend, the reader is referred to the web version of this article.) 
was no evidence of reassortment between isolates. The existence of a mutation on the anticodon inducing non-valylatability of PCV-S RNA-2 appeared to be an exception among the IPCV and PCV isolates, as suspected by Matsuda et al. (2000) and reported by Dreher (2009). This GAC valine anticodon and the capacity for efficient valylation are not considered essential properties for amplifying RNA-1 and RNA-2 (Matsuda et al., 2000) in contrast to the Turnip yellow mosaic virus (Tsai and Dreher, 1991), but valylatability gave a modest advantage to both PCV RNAs (Matsuda et al., 2000). In addition, the substitution in the D-loop did not affect the folding of the TLS conformation (Matsuda et al., 2000). This high degree of conservation between isolates confirmed the importance of this region in virus dispersion and survival.

\subsection{Broad-spectrum RT-PCR for detection and quantitation}

O. aspera (a weed) and $V$. subterranea (Bambara groundnut) have been shown to be natural IPCV and PCV host plants. V. subterranea plays an important part in diet of people of several West African countries (Nigeria, Ghana, Togo and Benin) where they are the most important commodity after cowpea (Vigna unguiculata) and groundnut. $V$. subterranea is often intercropped with pearl millet, sorghum or maize. IPCV and PCV were detected on $O$. aspera using RT-PCR and ELISA while viruses in $V$. subterranea could only be detected by RT-PCR. The effect of clump virus infection on $V$. subterranea is not known and the detection by RT-PCR would help. We presume that $O$. aspera and $V$. subterranea may play a role in the epidemiology of the peanut clump disease by contributing to increase in the infectious potential in already infested areas (Dieryck et al., 2009).

The presence of $3^{\prime}$-UTR numerous copies was due to the multipartite genome and the subgenomic RNAs produced from RNA-1 for the expression of P15 (Dunoyer et al., 2001), and from RNA-2 for the expression of Class1 (Morozov and Solovyev, 2003) Triple Gene Bloc movement proteins similar to Beet necrotic yellow vein virus and Barley stripe mosaic virus (Manohar et al., 1993). This high copy number makes the 3 '-UTR a logical target for highly efficient broad-spectrum detection. This strategy had already been used for detecting another virus also transmitted by Polymyxa, Soil-borne cereal mosaic virus (Vaianopoulos et al., 2009).

RT-PCR using J8-J9 primer pairs allowed all the currently known IPCV and PCV isolates to be detected. The PCR was 128 times more sensitive than ELISA. The technique was easy to use with direct sap extracts and can be applied under the conditions that exist in Africa and India by providing the necessary reagents and technical expertise.

In order to increase the sensitivity and specificity of the detection, and to quantify the virus, a quantitative real-time RT-PCR (RT-qPCR) was developed. From the sequencing of the $3^{\prime}$-UTR, primers and the Taqbd1 probe were designed. Due to the probe characteristic, the specificity to IPCV and PCV was very high and additionally this RT-qPCR can quantify all the currently known isolates. This method will be indispensable for identifying the source of resistance to clump disease and in determining the epidemiology. The quantitation technique was useful for IPCV and PCV studies, selection of resistant cultivars and maintenance of virusfree germplasm.

These techniques are very useful for detecting IPCV and PCV on unexpected host plants, a research area in progress as shown by Roossinck et al. (2010) with eco-genomic approaches. Further, a multiplex RT-PCR able to detect both the IPCV and PCV as developed for Beet necrotic yellow vein virus, Beet soil-borne virus and Beet virus $Q$ (Meunier et al., 2003) should be very useful to detect presence of pecluviruses in new areas. In order to understand better the interactions between cereals, IPCV/PCV and $P$. graminis, it would be interesting to combine the detection and quantitation methods already developed in a multiplex PCR targeting of both the virus and its vector.

\section{References}

Clamp, M., Cuff, J., Searle, S.M., Barton, G.J., 2004. The jalview java alignment editor Bioinformatics 12, 426-427.

Delfosse, P., Reddy, A.S., Thirumala Devi, K., Legrève, A., Risopoulos, J., Doucet, D. Shoba Devi, P., Maraite, H., Reddy, D.V.R., 2002. Dynamics of Polymyxa graminis and Indian peanut clump virus (IPCV) infection on various monocotyledonous crops and groundnut during the rainy season. Plant Pathol. 51, 546-560.

Dieryck, B., Otto, G., Doucet, D., Legrève, A., Delfosse, P., Bragard, C., 2009. Seed, soil and vegetative transmission contribute to the spread of pecluviruses in Western Africa and the Indian sub-continent. Virus Res. 141, 184-189.

Dreher, T.W., 2009. Role of tRNA-like structures in controlling plant virus replication. Virus Res. 139, 217-229.

Dunoyer, P., Herzog, E., Hemmer, O., Ritzenthaler, C., Fritsch, C., 2001. Peanut clump virus RNA-1-encoded $\mathrm{p} 15$ regulates viral RNA accumulation but is not abundant at viral RNA replication sites. J. Virol. 75, 1941-1948.

Goodwin, J.B., Dreher, T.W., 1998. Transfer RNA mimicry in a new group of positivestrand RNA plant viruses, the furoviruses: differential aminoacylation between the RNA components of one genome. Virology 246, 170-178.

Herzog, E., Guilley, H., Manohar, S.K., Dollet, M., Ricards, K., Fritsch, C., Jonard, G., 1994. Complete nucleotide sequence of Peanut clump virus RNA 1 and relationships with other fungus-transmitted rod-shaped viruses. J. Gen. Virol. 75 3147-3155.

Huguenot, C., Givord, L., Sommermeyer, G., Van Regenmortel, M.H., 1989. Differentiation of Peanut clump virus serotypes by monoclonal antibodies. Res. Virol. 140, 87-102.

Manohar, S.K., Dollet, M., Dubern, J., Gargani, D., 1995. Studies on variability of Peanut clump virus: symptomatology and serology. J. Phytopathol. 143, 233-238.

Manohar, S.K., Guilley, H., Dollet, M., Richards, K., Jonard, G., 1993. Nucleotide sequence and genetic organization of Peanut clump virus RNA 2 and partial characterization of deleted forms. Virology 195, 33-41.

Matsuda, D., Dunoyer, P., Hemmer, O., Fritsch, C., Dreher, T.W., 2000. The valine anticodon and valylatability of Peanut clump virus RNAs are not essential but provide a modest competitive advantage in plants. J. Virol. 74, 8720-8725.

Meunier, A., Schmit, J.-F., Stas, A., Kutluk, N., Bragard, C., 2003. Multiplex reverse transcription-PCR for simultaneous detection of Beet necrotic yellow vein virus, Beet soilborne virus, and Beet virus $Q$ and their vector Polymyxa betae KESKIN on sugar beet. Appl. Environ. Microbiol. 69, 2356-2360.

Miller, J.S., Wesley, S.V., Naidu, R.A., Reddy, D.V.R., Mayo, M.A., 1996. The nucleotide sequence of RNA-1 of Indian peanut clump furovirus. Arch. Virol. 141, 2301-2312.

Morozov, S.Y., Solovyev, A.G., 2003. Triple gene block: modular design of a multifunctional machine for plant virus movement. J. Gen. Virol. 84, 1351-1366.

Naidu, R.A., Miller, J.S., Mayo, M.A., Wesley, S.V., Reddy, A.S., 2000. The nucleotide sequence of Indian peanut clump virus RNA 2: sequence comparisons among pecluviruses. Arch. Virol. 145, 1857-1866.

Naidu, R.A., Sawyer, S., Deom, C.M., 2003. Molecular diversity of RNA-2 genome segments of pecluviruses causing peanut clump disease in West Africa and India. Arch. Virol. 148, 83-98.

Nolt, B.L., Rajeshwari, R., Reddy, D.V.R., Bharathan, N., Manohar, S.K., 1988. Indian peanut clump virus isolates: host ranges, sytmpomatology, serological relationships, and some physical properties. Etiology 78, 310-313.

Reddy, D.V.R., Bragard, C., Sreenivasulu, P., Delfosse, P., 2008. Pecluviruses. In: Mahy, B.W.J., Van Regenmortel, M. (Eds.), Encyclopedia of Virology, 4, 3rd ed. Oxford Academic Press, Boston, pp. 97-103.

Reddy, A.S., Hobbs, H.A., Delfosse, P., Murthy, A.K., Reddy, D.V.R., 1998. Seed transmission of Indian peanut clump virus (IPCV) in peanut and millets. Plant Dis. 82 343-346.

Roossinck, M.J., Saha, P., Wiley, G.B., Quan, J., White, J.D., Lai, H., Chavarria, F., Shen, G., Roe, B.A., 2010. Ecogenomics: using massively parallel pyrosequencing to understand virus ecology. Mol. Ecol. 19, 81-88.

Saitou, N., Nei, M., 1987. The neighbour-joining method--a new method for reconstructing phylogenetic trees. Mol. Biol. Evol. 4, 406-425.

Sundararaman, S., 1927. The clump disease of groundnuts. Madras Agricultural Department Yearbook 1926, 1927, pp. 13-14.

Tamura, K., Dudley, J., Nei, M., Kumar, S., 2007. MEGA4: Molecular Evolutionary Genetics Analysis (MEGA) software version 4.0. Mol. Biol. Evol. 24, 1596-1599.

Thomson, D., Dietzgen, R.G., 1995. Detection of DNA and RNA plant viruses by PCR and RT-PCR using a rapid virus release protocol without tissue homogenisation. J. Virol. Methods 54, 85-95.

Torrance, L., Mayo, M.A., 1997. Proposed reclassification of furoviruses. Arch. Virol. $142,435-439$.

Trochain, J., 1931. La "lèpre de l'arachide". Revue de botanique appliquée et d'agriculture tropicale 11, 330-334.

Tsai, C.H., Dreher, T.W., 1991. Turnip yellow mosaic virus RNAs with anticodon loop substitutions that result in decreased valylation fail to replicate efficiently. J. Virol. 65, 3060-3067.

Vaianopoulos, C., Legrève, A., Moreau, V., Bragard, C., 2009. Broad-spectrum detection and quantitation methods of soil-borne cereal mosaic virus isolates. J. Virol. Methods 159, 227-232.

Wesley, S.V., Miller, J.S., Devi, P.S., Delfosse, P., Naidu, R.A., Mayo, M.A., Reddy, D.V.R. Jana, M.K., 1996. Sensitive broad-spectrum detection of Indian peanut clump virus by nonradioactive nucleic acid probes. Phytopathology 86, 1234-1237. 